\title{
THE WORD "SHOOT" ANALYZED BY NATURAL SEMANTIC METALANGUAGE
}

\author{
Putu Indry Prabhaswari \\ Linguistics Program in Translation Studies, Universitas Udayana \\ e-mail:prabhaswari@email.com \\ Made Budiarsa \\ Linguistics Program in Translation Studies, Universitas Udayana \\ e-mail: made_budiarsa@yahoo.com \\ Ida Ayu Made Puspani \\ Linguistics Program in Translation Studies, Universitas Udayana \\ e-mail: dayupuspani@gmail.com
}

\begin{abstract}
This study is focusing on the mapping of word shoot meanings. The collected data was qualitatively analyzed, it was starting by reading some sources, finding a word to be analyzed, reading carefully the source text and the target text, taking note, analyzed the text by NSM approach by Wierzbicka (1999). The data in this writing was taken from Colour Magazine Garuda Indonesia and used one of the prevalent comic series of Tintin entitled The Adventures of Tintin: Tintin in America and Tintin the shooting star. The technique of this study were three steps, they are finding the word which want to analyzed, read the text carefully, finding the word with its translation which want to discuss, directly noted the word which was according to the topic. The result of this study showed that the findings of three meanings of one word shoot. Some of the translation could convey the meaning therefore the reader in target language is easily read and understood.
\end{abstract}

Keywords: shoot, natural semantic metalanguage, three meaning

\section{INTRODUCTION}

Translation is very important in globalization era because many printed media used English as the language which English is the most commonly spoken language in the world (Baker, 2001). Globalization is the increasingly of relations of people, culture and economy. Despite the common usage of the term globalization started in 1970s and some scholars claim the real globalization is ancient. The concept of English language known as 'International English' is the global view of the language or the international standard for the language (Clyne \& Sharifian, 2008). It can also be referred as: Global English, World English or even Globish. Despite the arguing if it is a desired standardization or killing of the language, the focus here is to show that it is globally acknowledged to be the most global language of all times. The term can also refer to the transnational circulation of ideas, languages, and popular culture.

Garuda Indonesia Colours Magazine is the standard of interactive content creation and distribution. Joomag's flagship Crater ${ }^{\mathrm{TM}}$ Editor was designed with this philosophy in mind. It provides an unprecedented online experience, allowing users to 
create powerful publications, deliver them in innovative ways, and engage readers from every corner of the world. This magazine published around the world and good as data of translation analyzes.

A comic book is a periodical publication that tells a tale through visuals. There are various challenges with translating comics that are not present in other writings. For example, a comic book translator should be able to select short terms that match the capacity in the bubbles. Aside from that, comic translators have to develop their imagination by utilizing the appropriate language to immerse readers in the plot . Making a good translation of a comic, the translators usually used common strategy which is loss and gain. And this is the subject of the researcher's investigation.

This study used one of Tintin's most popular series, "The Adventures of Tintin: Tintin in America." This honorific title was composed in 1931 and initially published in 1932, before being reissued in 2002. The researcher has used this comic because it contains something intriguing. Tintin was first published in Belgian and then translated into a variety of languages, including English, so the data utilized by the researcher is a translation of the translated comic. This comic's English and Indonesian versions are compared by the researcher.

The theory used in this study is The Natural Semantic Metalanguage (NSM) which is a decompositional system of meaning representation based on empirically established universal semantic primes, i.e., simple indefinable meanings which appear to be present as word-meanings in all languages (Goddard, 1998, 2008, 2011; Goddard \& Wierzbicka, 2002; Wierzbicka, 1996; Wierzbicka \& Peeters, 2006). Originating with Wierzbicka (1972) the system has been developed and refined over some 35 years.

\section{METHOD}

The data of the analysis were taken from 'Colour Magazine Garuda Indonesia' and used one of the popular series of Tintin entitled "The Adventures of Tintin: Tintin in America" and "Tintin the shooting star". In Colour Magazine Garuda Indonesia, it printed two kinds of language, they are English and Indonesia. From the magazine it was picked one article about macro photography in page 24 series February 2018. Because topic about culture so interesting to analyze.

The Natural Semantic Metalanguage (NSM) is a decompositional system of meaning representation based on empirically established universal semantic primes, i.e., simple indefinable meanings which appear to be present as word-meanings in all languages (Goddard, 1998, 2008, 2011; Goddard \& Wierzbicka, 2002; Wierzbicka, 1996; Wierzbicka \& Peeters, 2006). Originating with Wierzbicka (1972) the system has been developed and refined over some 35 years.

The NSM approach grew out of lexical semantics, and it still accords much greater importance to lexical semantics than many rival approaches, but the approach has long since extended into grammatical and illocutionary semantics, and (with the theory of cultural scripts) into cultural pragmatics. Adopting a uniform method of meaning description across these domains allows for the integration of areas of linguistic structure that often appear disparate and disconnected in other models.

The method which is used in this study for collecting data are descriptivequalitative that focuses on translation product analysis. Descriptive-qualitative method is the method which is done by systematically way, therefore the data were listed organizationally. The method and technique of collecting can be done in three steps finding the word which want to analyzed, read the text carefully, finding the word with 
its translation which want to discuss, directly noted the word which was according to the topic. The method and technique of analyzing data is the data were analyzed briefly by mapping using the theory of NSM proposed by Wierzbicka (1996). Finally, the problems were solved and the result of the research could be shared and learnt.

\section{FINDINGS AND DISCUSSION}

There are some meaning found in one word 'shoot' based on the context of situation. It was found the first word shoot in Tintin comic and will analyze by Natural Semantic Metalanguage approach.

Table 1. The First Word Shoot in Tintin Comic

\begin{tabular}{lll}
\hline \multicolumn{2}{c}{ SL } & \multicolumn{2}{c}{ TL } \\
\hline $\begin{array}{l}\text { Move one muscle, and I'll shoot } \\
\text { your brains! }\end{array}$ & $\begin{array}{l}\text { Bergerak sedikit saja ku tembak } \\
\text { kepala kalian! }\end{array}$ \\
\hline
\end{tabular}

From the data above there is found a word 'shoot' in the comic. Based on the situation and using of the word 'shoot' the translator translate it become 'tembak'. Because from the picture also explain the meaning of the word. Based on KBBI (Kamus Besar Bahasa Indonesia) tembak means: release the bullet or something from the weapon, to pointing to someone or something; to bringing the ball to the goalpost, to taking picture of someone or something (KBBI Daring, 2021). But in this case the translator chose the meaning of shoot as tembak because it was clear can be seen in the picture also in the context of situation of the word.

\section{The explication of 'shoot' in the first situation}

$\mathrm{X}$ want to make $\mathrm{Y}$ feel something

$\mathrm{X}$ want to $\mathrm{Y}$ think something

$\mathrm{X}$ think Y will move

$\mathrm{X}$ will do something (Shooting) by something (gun) to $\mathrm{Y}$

$\mathrm{X}$ think by doing something (shooting), can be something to $\mathrm{Y}$

The word 'shoot' was translated into Indonesian becomes tembak. It can be seen that the SL word was translated literally. The entity of the word 'shoot can be the action verb then the process of this word is Release or fires something (bullet/arrow) from something it could be gun, rifle, shotgun, row. The equipment to do this action are gun, rifle, shotgun, slingshot, air rifle, and row then the result of this action are broke, dead, hole, and wound

\section{The explication of 'tembak'}

$\mathrm{X}$ want to $\mathrm{Y}$ did not do something to $\mathrm{X}$

$\mathrm{X}$ want to make $\mathrm{Y}$ far from $\mathrm{X}$ 
$\mathrm{X}$ want to $\mathrm{Y}$ do something (give up)

$\mathrm{X}$ do something (hurting) Y by something (gun)

The both explication above show the meaning of the word 'shoot' which can be more than one meaning in Indonesian. Also can be configured it based on the context of situation in the text. The character of the word 'shoot' become 'memotret' can be seen from the object of the action verb. If the object of action verb is about picture and photo, therefor the word 'shoot' can be easily to translate.

Table 2. The Word 'Shoot' Means 'Memotret'

\begin{tabular}{ll}
\hline \multicolumn{1}{c}{ SL } & \multicolumn{1}{c}{ TL } \\
\hline $\begin{array}{l}\text { A shooting star! Quick snowy I } \\
\text { wish! }\end{array}$ & $\begin{array}{l}\text { Bintang Jatuh! Cepat Snowy } \\
\text { sebut keinginanmu! }\end{array}$ \\
$\begin{array}{ll}\text { If I were you I stop wishing and look } \\
\text { where I was going. }\end{array}$ & $\begin{array}{l}\text { Jangan berkhayal lihatlah } \\
\text { kedepan kalau sedang berjalan. }\end{array}$ \\
\hline
\end{tabular}

From the data above there is found a word 'shoot' in the comic. Based on the situation and using of the word 'shoot' the translator translated it becoming 'Jatuh'. Because from the picture also explain the meaning of the word. Based on Indonesian Dictionary (KBBI Daring, 2021) tembak means: release the bullet or something from the weapon, to pointing to someone or something; to bringing the ball to the goalpost, to taking picture of someone or something. But in this case the translator chose the meaning of shoot as jatuh because it was clear can be seen in the picture also in the context of situation of the word.

\section{The explication of 'shoot' in the first situation}

$\mathrm{X}$ think something (a wish)

$\mathrm{X}$ think something good

$\mathrm{X}$ say something big

$\mathrm{X}$ say kind of something (star)

\section{The explication of 'jatuh'}

$\mathrm{X}$ think something (a wish)

$\mathrm{X}$ think something good

$\mathrm{X}$ say something big

$\mathrm{X}$ say kind of something (star)

The both explication above show the meaning of the word 'shoot' which can be more than one meaning in Indonesian. Also can be configured it based on the context of situation in the text. The character of the word 'shoot' become 'jatuh' can be seen from 
the object of the action verb. In this case the word 'shoot' become adjective and modify the word star, therefore the explication becoming as previous paragraph.

Table 3. The Word 'Shoot' Means 'Jatuh'

SL

I never shoot as black and white as I

find colour inspiring and invigorating. My world is a passionately colourful one and I love it
TL

Saya tak pernah memotret hitam putih karena bagi saya warna itu inspiratif dan menyegarkan. Dunia saya penuh warna dan saya menyukainya.

From the data above there is found a word 'shoot'. Based on the situation and using of the word 'shoot' the translator translate it become 'memotret'. Because from the picture beside the text in the magazine also explain the meaning of the word. Based on KBBI Daring (2021) tembak means: release the bullet or something from the weapon, to pointing to someone or something; to bringing the ball to the goalpost, to taking picture of someone or something. But in this case the translator chose the meaning of shoot as memotret because it was clear can be seen in context of situation of the word.

\section{The explication of 'shoot' in the first situation}

$\mathrm{X}$ do something to something (object)

$\mathrm{X}$ move something (camera) to do something

$\mathrm{X}$ feel something about something (object photo)

$\mathrm{X}$ see something good

\section{The explication of 'memotret'}

$\mathrm{X}$ do something to something (object)

$\mathrm{X}$ move something (camera) to do something

$\mathrm{X}$ feel something about something (object photo)

$\mathrm{X}$ see something good

The both explication above show the meaning of the word 'shoot' which can be more than one meaning in Indonesian. Also can be configured it based on the context of situation in the text. The character of the word 'shoot' become 'memotret' can be seen from the object of the action verb. If the object of action verb is about picture and photo, therefor the word 'shoot' can be easily to translate. 


\section{CONCLUSION AND SUGGESTION}

The meaning of shoot in general based on Oxford dictionary are many, but from the data (comic and magazine) that found the verb shoot it means, tembak, jatuh and memotret. The NSM provides a tool for cross-cultural analysis of emotion concepts. The application of the NSM approach to translation can shed light on the difficult process of translating emotions.

\section{REFERENCES}

Baker, M. (2001). Routledge Encyclopedia of Translation Studies. Routledge.

Clyne, M., \& Sharifian, F. (2008). English as an International Language: Challenges and Possibilitirs. Australian Review of Applied Linguistics, 31(3), 1-16. https://doi.org/10.1111/j.1467-971X.1993.tb00019.x

Goddard, C. (1998). Semantic Analysis: A Practical Introduction. Oxford University Press.

Goddard, C. (2008). Natural Semantic Metalanguage: The state of the art. In C. Goddard (Ed.), Cross-Linguistic Semantics. John Benjamin Publishing.

Goddard, C. (2011). Semantic Analysis: A Practical Introduction (2nd ed.). Oxford University Press.

Goddard, C., \& Wierzbicka, A. (2002). Semantic Prime and Universal Grammar. In C. Goddard \& A. Wierzbicka (Eds.), Meaning and Universal Grammar: Theory and Empirical Findings. John Benjamin Publishing.

KBBI Daring. (2021). Kemendikbud.Go. https://kbbi.kemdikbud.go.id/entri/tembak

Wierzbicka, A. (1972). Semantic Primitives. Athena“um.

Wierzbicka, Anna. (1996). Emotions Across Languages and Cultures. Oxford University Press.

Wierzbicka, Anna. (1999). Emotions Across Languages and Cultures. Cambridge University Press.

Wierzbicka, Anna, \& Peeters, B. (2006). The Natural Semantic Metalanguage (NSM) approach. In B. Peeters (Ed.), Semantic Primes and Universal Grammar. John Benjamin Publishing. 